\title{
Impact of heating rate and solvent on Ni-based catalysts prepared by solution combustion method for syngas methanation
}

\author{
Yan Zeng, Hongfang Ma, Haitao Zhang, Weiyong Ying*, Dingye Fang \\ East China University of Science and Technology, Engineering Research Center of Large Scale Reactor Engineering and \\ Technology, Ministry of Education, State Key Laboratory of Chemical Engineering, Shanghai, China 200237 \\ "Corresponding author: e-mail: wying@ecust.edu.cn
}

\begin{abstract}
$\mathrm{Ni}-\mathrm{Al}_{2} \mathrm{O}_{3}$ catalysts prepared by solution combustion method for syngas methanation were enhanced by employing various heating rate and different solvent. The catalytic properties were tested in syngas methanation. The result indicates that both of heating rate and solvent remarkably affect Ni particle size, which is a key factor to the catalytic activity of $\mathrm{Ni}_{-} \mathrm{Al}_{2} \mathrm{O}_{3}$ catalysts for syngas methanation. Moreover, the relationship between $\mathrm{Ni}$ particle size and the production rate of methane per unit mass was correlated. The optimal $\mathrm{Ni}_{-} \mathrm{Al}_{2} \mathrm{O}_{3}$ catalyst prepared in ethanol at $2^{\circ} \mathrm{C} / \mathrm{min}$, achieves a maximum production rate of methane at the mean size of $20.8 \mathrm{~nm}$.
\end{abstract}

Keywords: nickel catalysts, syngas methanation, solution combustion method.

\section{INTRODUCTION}

Natural gas has been considered as a promising energy source because of its clean nature, high calorific value and easiness for complete combustion. However, due to its poor reserves in some regions of the world, synthetic natural gas (SNG) plays an important role as an alternative energy ${ }^{1,2}$. Therefore, syngas methanation as a useful technology to synthesize natural gas, has attracted much attention from both academia and industry $^{3,4}\left(\mathrm{CO}+3 \mathrm{H}_{2} \rightarrow \mathrm{CH}_{4}+\mathrm{H}_{2} \mathrm{O}, \Delta \mathrm{H}_{298 \mathrm{~K}}=-206.1\right.$ $\mathrm{kJ} \cdot \mathrm{mol}^{-1} ; \mathrm{CO}_{2}+4 \mathrm{H}_{2} \rightarrow \mathrm{CH}_{4}+2 \mathrm{H}_{2} \mathrm{O}, \Delta \mathrm{H}_{298 \mathrm{~K}}=-165.0$ $\left.\mathrm{kJ} \cdot \mathrm{mol}^{-1}\right)$. Since Sabatier and Senderens discovered that some metals such as $\mathrm{Ni}, \mathrm{Ru}, \mathrm{Rh}, \mathrm{Pt}, \mathrm{Fe}$, and Co possessed a good catalytic activity for syngas methanation in $1902^{5}$, methanation catalysts integrating active metal had been developed well. Ru-based catalysts retain the best active for syngas methanation, but limited resource and high cost restrict their large-scale commercialization $^{6-8}$. Ni-based catalysts have been widely used for their low cost, high catalytic activity and selectivity for methane ${ }^{9-11}$. In recent decades, great efforts have been made to produce high-efficiency catalysts retaining high activity at low-temperature (ca. $300^{\circ} \mathrm{C}$ ) and high stability at high-temperature (ca. $\left.600^{\circ} \mathrm{C}\right)$. Since Ni-based catalysts prepared by conventional methods (coprecipitation, impregnation, sol-gel and mechanical mixing) possess low activity at low-temperature, and deactivate easily at hightemperature, Zhao et al. employed solution combustion method (SCM) to synthesize Ni-based catalysts for CO methanation ${ }^{12}$, which shows excellent catalytic activity and stability. The aim of our work is to further improve and optimize the SCM by investigating the condition of preparation process.

In this work, we employ various heating rate $\left(2^{\circ} \mathrm{C}\right.$. $\min ^{-1}, 5^{\circ} \mathrm{C} \cdot \min ^{-1}$ and $\left.10^{\circ} \mathrm{C} \cdot \min ^{-1}\right)$ and different solvent (ethanol, n-propanol and glycerol) to prepare $\mathrm{Ni}-\mathrm{Al}_{2} \mathrm{O}_{3}$ catalysts by SCM. The as-synthesized catalysts were characterized by $\mathrm{N}_{2}$ adsorption-desorption, XRD, $\mathrm{H}_{2-}$ TPR and TEM. Effects of heating rate and solvent on $\mathrm{CO}$ conversion and stability, as well as the relationship between Ni particle size and production rate of methane per unit mass of $\mathrm{Ni}$ were studied.

\section{EXPERIMENTAL}

\section{Catalyst preparation}

$\mathrm{Ni}\left(\mathrm{NO}_{3}\right)_{2} \cdot 6 \mathrm{H}_{2} \mathrm{O}$ and $\mathrm{Al}\left(\mathrm{NO}_{3}\right)_{3} \cdot 9 \mathrm{H}_{2} \mathrm{O}$ were used as metal precursor salts. Ethanol, n-propanol and glycerol were used as the solvent and fuel. Typically, $14.87 \mathrm{~g}$ $\mathrm{Ni}\left(\mathrm{NO}_{3}\right)_{2} \cdot 6 \mathrm{H}_{2} \mathrm{O}$ and $51.52 \mathrm{~g} \mathrm{Al}\left(\mathrm{NO}_{3}\right)_{3} \cdot 9 \mathrm{H}_{2} \mathrm{O}$ were dissolved in $200 \mathrm{~mL}$ ethanol at room temperature, while the same amount of metal precursor salts were dissolved in $200 \mathrm{~mL} \mathrm{n}$-propanol and glycerol respectively, which were preheated in water bath at $70^{\circ} \mathrm{C}$. These mixtures were vigorously stirred until $\mathrm{Ni}$ and $\mathrm{Al}$ salts completely dissolved, and then kept at $70^{\circ} \mathrm{C}$ for $6 \mathrm{~h}$ to ensure these solutions at the same initial temperature. After that, these stable and clear solutions were heated from 70 to $700^{\circ} \mathrm{C}$ under static air in a muffle furnace with given heating rate (combustion occurred spontaneously during the heating process), and then kept at $700^{\circ} \mathrm{C}$ for $7 \mathrm{~h}$. The prepared $\mathrm{Ni}-\mathrm{Al}_{2} \mathrm{O}_{3}$ catalysts were denoted as $30 \mathrm{Ni}-\mathrm{XY}$, where 30 showed $\mathrm{Ni}$ weight content in the catalyst, $\mathrm{X}$ represented the heating rate $\left({ }^{\circ} \mathrm{C}\right.$. $\left.\mathrm{min}^{-1}\right)$ and $\mathrm{Y}$ indicated the type of solvent $(\mathrm{E}=$ ethanol, $\mathrm{P}=\mathrm{n}$-propanol and $\mathrm{G}=$ glycerol). For comparison, pure $\mathrm{Al}_{2} \mathrm{O}_{3}$ was also prepared at $2^{\circ} \mathrm{C} \cdot \mathrm{min}^{-1}$ using ethanol as solvent.

\section{Catalyst characterization}

Nitrogen adsorption-desorption isotherms were obtained with Micrometrics ASAP 2020 apparatus. Prior to $\mathrm{N}_{2}$ adsorption, the samples were degassed under vacuum at $200^{\circ} \mathrm{C}$ for $4 \mathrm{~h}$. Specific surface areas were measured by Brunauer Emmet Teller (BET) method. Total pore volume and pore sizes were evaluated using the standard Barrett-Joyner-Halenda (BJH) treatment.

Powder X-ray diffraction (XRD) patterns were recorded on a Rigaku D/Max 2550 using $\mathrm{Cu}$ Karadiation at $40 \mathrm{kV}$ and $100 \mathrm{~mA}$. XRD patterns were determined over a $2 \theta$ range of $10-80^{\circ}$ and a step size of $0.02^{\circ}$.

Hydrogen temperature programmed reduction $\left(\mathrm{H}_{2}-\right.$ -TPR) measurements were carried out on AutoChem II 2920 (Micrometrics) instrument. Prior to the $\mathrm{H}_{2}$ TPR measurements, $200 \mathrm{mg}$ sample placed in a quartz U-tube reactor was pretreated in $\mathrm{Ar}$ stream at $500^{\circ} \mathrm{C}$ for $0.5 \mathrm{~h}$ and then cooled to $50^{\circ} \mathrm{C} . \mathrm{H}_{2}$-TPR process was 
then conducted with a gas mixture of 10 vol. $\% \mathrm{H}_{2}$ in Ar at the flow rate of $50 \mathrm{~mL} \cdot \mathrm{min}^{-1}$, and temperature was raised from 50 to $1000^{\circ} \mathrm{C}$ with the heating rate of $10^{\circ} \mathrm{C} \cdot \mathrm{min}^{-1}$. Hydrogen consumption was monitored by thermal conductivity detector (TCD).

Transmission electron microscope (TEM) images were taken by means of a JEM-1400 apparatus operated at 100 $\mathrm{kV}$. In order to obtain the suitable samples, the metal oxides catalysts were reduced to the metallic state in $\mathrm{H}_{2}$ atmosphere $\left(100 \mathrm{~mL} \cdot \mathrm{min}^{-1}\right)$ for $3 \mathrm{~h}$ at $700^{\circ} \mathrm{C}$, and cooled to room temperature in $\mathrm{N}_{2}$ flow, then passivated in $\mathrm{O}_{2} / \mathrm{N}_{2}$ mixture $\left(1\right.$ vol. $\left.\% \mathrm{O}_{2}, 100 \mathrm{~mL} \cdot \mathrm{min}^{-1}\right)$ for $2 \mathrm{~h}$ to avoid bulk oxidation of $\mathrm{Ni}$ nanoparticles ${ }^{6}$. After that, the reduced Ni-based catalysts were dispersed in ethanol by ultrasonic, and the suspension was then dropped onto a holey carbon-coated copper grid.

\section{Syngas methanation}

Syngas (carbon oxides and hydrogen) methanation reaction was carried out in a fixed-bed reactor $(\Phi 14 \times 2 \times 500 \mathrm{~mm})$. Inert $\mathrm{Al}_{2} \mathrm{O}_{3}$ was added at both ends of the uniform temperature zone to keep the catalyst in the middle. Typically $500 \mathrm{mg}$ catalyst was used, and the total gas flow rate was $100 \mathrm{~mL} \cdot \mathrm{min}^{-1}$, corresponding to a weight hourly space velocity (WHSV) of 12000 $\mathrm{mL} \cdot \mathrm{g}^{-1} \cdot \mathrm{h}^{-1}$. The catalyst was heated from ambient temperature to $700^{\circ} \mathrm{C}$ in nitrogen flow within $300 \mathrm{~min}$ and reduced by pure hydrogen for $3 \mathrm{~h}$. Afterwards, the catalyst was cooled to reaction temperature under nitrogen flow, and then the reaction was initiated as the gas flow switched to the syngas $(17.3$ vol.\% CO, 9.5 vol.\% $\mathrm{CO}_{2}, 67.7$ vol. $\% \mathrm{H}_{2}, 5.5$ vol. $\% \mathrm{~N}_{2}$ ) to investigate the low-temperature catalytic activity of $\mathrm{Ni}$-based catalysts at $260-340^{\circ} \mathrm{C}, 0.1 \mathrm{MPa}$ and $12000 \mathrm{~mL} \cdot \mathrm{g}^{-1} \cdot \mathrm{h}^{-1}$. Hightemperature stability test of $30 \mathrm{Ni}-\mathrm{Al}_{2} \mathrm{O}_{3}$ was conducted at $600^{\circ} \mathrm{C}, 2 \mathrm{MPa}, 12000 \mathrm{~mL} \cdot \mathrm{g}^{-1} \cdot \mathrm{h}^{-1}$ and with $30 \mathrm{~mol} \%$ water. Here, we define:

CO conversion: $X_{\mathrm{CO}}(\%)=\frac{N_{\mathrm{CO}, \text { in }}-N_{\mathrm{CO}, \text { out }}}{N_{\mathrm{CO}, \text { in }}} \times 100$

$\mathrm{CO}_{2}$ conversion: $X_{\mathrm{CO}_{2}}(\%)=\frac{N_{\mathrm{CO}_{2}, \text { in }}-N_{\mathrm{CO}_{2}, \text { out }}}{N_{\mathrm{CO}_{2} \text {, in }}} \times 100$

$\mathrm{CH}_{4}$ selectivity:

$S_{\mathrm{CH}_{4}}(\%)=\frac{N_{\mathrm{CH}_{4}, \text { out }}}{\left(N_{\mathrm{CO}, \text { in }}-N_{\mathrm{CO}, \text { out }}\right)+\left(N_{\mathrm{CO}_{2}, \text { in }}-N_{\mathrm{CO}_{2}, \text { out }}\right)} \times 100$

$\mathrm{CH}_{4}$ formation rate: $r_{\mathrm{CH}_{4}}=\frac{N_{\mathrm{CH}_{4}, \text { out }}}{m_{\mathrm{Ni}}}$
$\mathrm{N}$ is the mole flow rate $\left(\mathrm{mol} \cdot \mathrm{h}^{-1}\right)$, and $\mathrm{m}$ is the weight of $\mathrm{Ni}(\mathrm{g})$.

\section{RESULTS AND DISCUSSION}

The surface area $\left(\mathrm{S}_{\mathrm{BET}}\right)$, pore volume $\left(\mathrm{V}_{\mathrm{P}}\right)$ and average pore size $\left(D_{P}\right)$ of the Ni-based catalysts are summarized in Table 1. The surface area, pore volume and average pore size of the $\mathrm{Ni}-\mathrm{Al}_{2} \mathrm{O}_{3}$ catalysts are 85.2 $150.3 \mathrm{~m}^{2} \cdot \mathrm{g}^{-1}, 0.165-0.637 \mathrm{~cm}^{3} \cdot \mathrm{g}^{-1}$ and $4.3-26.8 \mathrm{~nm}$, respectively. It can be found that there exist a little difference of pore volume and average pore size among the catalysts except $30 \mathrm{Ni}-2 \mathrm{G}$, which obtains the highest pore volume of $0.637 \mathrm{~cm}^{3} \cdot \mathrm{g}^{-1}$ and average pore size of $26.8 \mathrm{~nm}$. Moreover, heating rate contributes to the surface area and pore volume little, while solvent type plays the most important role.

XRD patterns of fresh calcined $\mathrm{Ni}-\mathrm{Al}_{2} \mathrm{O}_{3}$ catalysts as well as pure $\mathrm{Al}_{2} \mathrm{O}_{3}$ are shown in Figure 1a. For pure $\mathrm{Al}_{2} \mathrm{O}_{3}$, three board diffraction peaks of $\gamma-\mathrm{Al}_{2} \mathrm{O}_{3}$ (JCPDS 10-0425) are presented. For fresh calcined $\mathrm{Ni}-\mathrm{Al}_{2} \mathrm{O}_{3}$ catalysts, the diffraction peaks at $37.3^{\circ}, 43.2^{\circ}, 62.9^{\circ}, 75.3^{\circ}$ and $79.4^{\circ}$ are attributed to distinct peaks of cubic $\mathrm{NiO}$ (JCPDS 73-1519), and the diffraction peaks at $19.1^{\circ}$, $31.4^{\circ}, 37.0^{\circ}, 45.0^{\circ}, 59.7^{\circ}$ and $65.9^{\circ}$ derive from distinct peaks of $\mathrm{NiAl}_{2} \mathrm{O}_{4}$ (JCPDS 10-0339). Moreover, the average crystal diameters of $\mathrm{NiO}$ are estimated from (311) plane using Scherrer equation. As shown in Table 1, the mean crystal diameter of $\mathrm{NiO}\left(\mathrm{D}_{\mathrm{NiO}}\right)$ gradually increases from 31.9 to $36.9 \mathrm{~nm}$ when the heating rate increases from 2 to $10^{\circ} \mathrm{C} \cdot \mathrm{min}^{-1}$. The result can be attributed to the increase of heating rate which leads to higher flame temperature, and thereby aggravating the aggregation of $\mathrm{Ni}$ particles. In addition, $\mathrm{D}_{\mathrm{NiO}}$ of $\mathrm{Ni}-\mathrm{Al}_{2} \mathrm{O}_{3}$ catalysts prepared in n-propanol and glycerol is smaller than that in ethanol, which implies that solvent has an effect on Ni particle size.

XRD patterns of reduced $\mathrm{Ni}-\mathrm{Al}_{2} \mathrm{O}_{3}$ catalysts and pure $\mathrm{Al}_{2} \mathrm{O}_{3}$ are presented in Figure 1b. The diffraction peaks at $44.3^{\circ}, 51.7^{\circ}$ and $76.1^{\circ}$ are attributed to distinct peaks of Ni (JCPDS65-0380). As shown in Figure 1b, diffraction peaks of $\mathrm{NiAl}_{2} \mathrm{O}_{4}$ still exist in the reduced $\mathrm{Ni}-\mathrm{Al}_{2} \mathrm{O}_{3}$ catalysts, which indicate that $\mathrm{NiAl}_{2} \mathrm{O}_{4}$ is difficult to be reduced. Furthermore, the average crystal diameter of $\mathrm{Ni}$ $\left(\mathrm{D}_{\mathrm{Ni}}\right)$ calculated from (200) plane is in good agreement with the average crystal diameter of $\mathrm{NiO}$.

TPR results of all the $\mathrm{Ni}-\mathrm{Al}_{2} \mathrm{O}_{3}$ catalysts were shown in Figure 2, in which the various peak temperatures reveal the different interaction between nickel oxides and alumina. According to the peaks in their TPR profiles

Table 1. Surface area, pore volume, average pore diameter and $\mathrm{NiO}$ crystal size for fresh calcined $\mathrm{Ni}-\mathrm{Al}_{2} \mathrm{O}_{3}$ catalysts, $\mathrm{Ni}$ crystal size for reduced $\mathrm{Ni}-\mathrm{Al}_{2} \mathrm{O}_{3}$ catalysts, and production rate of methane per unit mass of nickel $\left(\mathrm{rCH}_{4}\right)$

\begin{tabular}{|c|c|c|c|c|c|c|c|}
\hline Catalyst & $\begin{array}{c}\mathrm{S}_{\mathrm{BET}} \\
{\left[\mathrm{m}^{2} \cdot \mathrm{g}^{-1}\right]}\end{array}$ & $\begin{array}{c}V_{p}^{a} \\
{\left[\mathrm{~cm}^{3} \cdot \mathrm{g}^{-1}\right]}\end{array}$ & $\begin{array}{l}\mathrm{D}_{\mathrm{p}}^{\mathrm{b}} \\
{[\mathrm{nm}]}\end{array}$ & $\begin{array}{l}\mathrm{D}_{\mathrm{NiO}}{ }^{\mathrm{c}} \\
{[\mathrm{nm}]}\end{array}$ & $\begin{array}{l}D_{N i}{ }^{c} \\
{[n m]}\end{array}$ & $\begin{array}{c}\mathrm{D}_{\mathrm{Ni}}{ }^{\mathrm{d}} \\
{[\mathrm{nm}]}\end{array}$ & {$\left[\begin{array}{c}r_{\mathrm{CH} 4} \\
{\left[\mathrm{mmol} \cdot \mathrm{g}^{-1} \cdot \mathrm{h}^{-1}\right]}\end{array}\right.$} \\
\hline $30 \mathrm{Ni}-2 \mathrm{E}$ & 110.2 & 0.188 & 4.9 & 31.9 & 20.8 & 22.0 & 221 \\
\hline $30 \mathrm{Ni}-5 \mathrm{E}$ & 121.2 & 0.209 & 5.0 & 32.3 & 21.6 & 26.2 & 92 \\
\hline $30 \mathrm{Ni}-10 \mathrm{E}$ & 120.1 & 0.165 & 4.3 & 36.9 & 29.9 & 30.1 & 50.3 \\
\hline 30Ni-2P & 150.3 & 0.253 & 4.8 & 27.9 & 17.5 & 18.8 & 61.6 \\
\hline $30 \mathrm{Ni}-2 \mathrm{G}$ & 85.2 & 0.637 & 26.8 & 20.5 & 10.0 & 16.7 & 44.8 \\
\hline
\end{tabular}

${ }^{a} \mathrm{BJH}$ desorption pore volume,

${ }^{\text {b}} \mathrm{BJH}$ desorption average pore diameter,

${ }^{\mathrm{C}}$ Calculated from XRD using Scherrer equation,

${ }^{\mathrm{d}}$ Measured by TEM photo (Ni average diameter $=\Sigma n_{\mathrm{i}} \mathrm{d}_{\mathrm{i}}{ }^{3} / S n_{\mathrm{i}} \mathrm{d}_{\mathrm{i}}{ }^{2}$ ). 

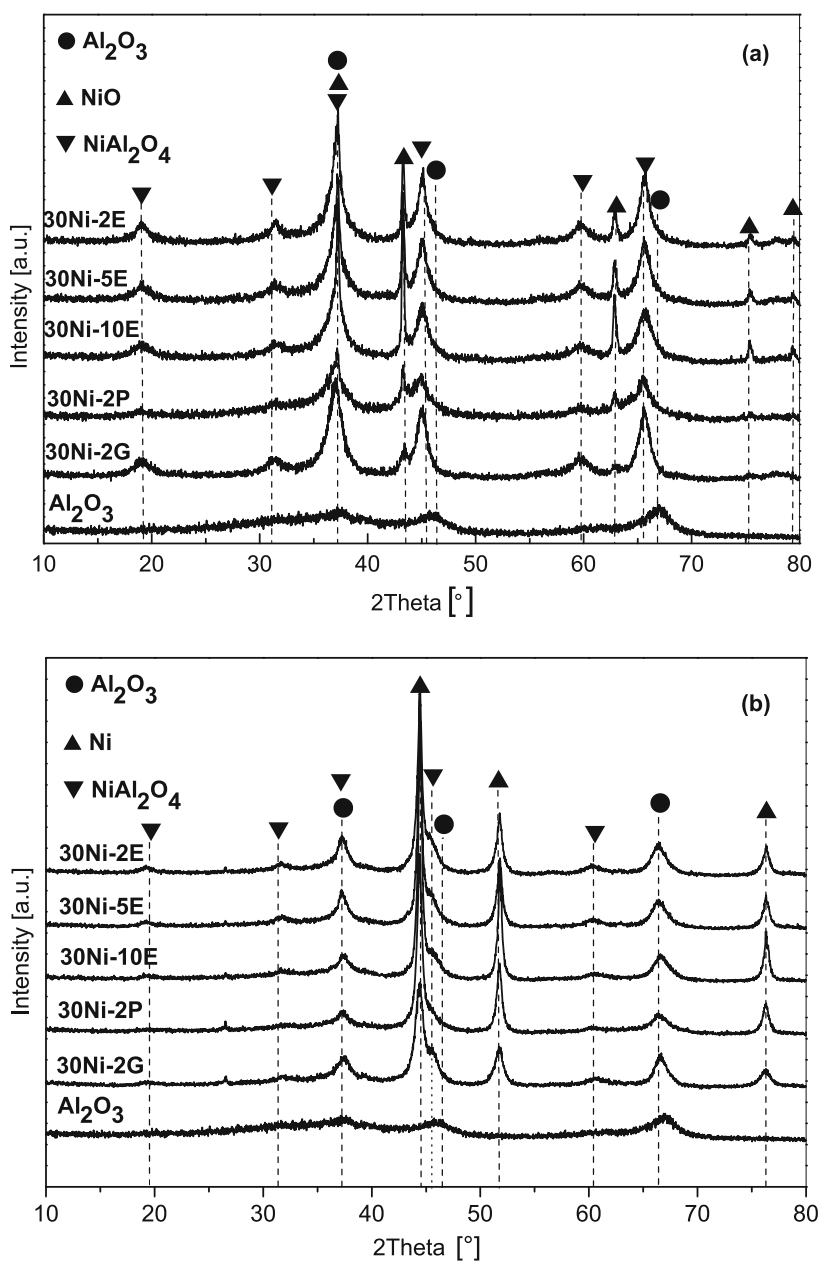

Figure 1. $\mathrm{XRD}$ patterns of fresh calcined $\mathrm{Ni}-\mathrm{Al}_{2} \mathrm{O}_{3}$ catalysts (a), and reduced $\mathrm{Ni}-\mathrm{Al}_{2} \mathrm{O}_{3}$ catalysts (b)

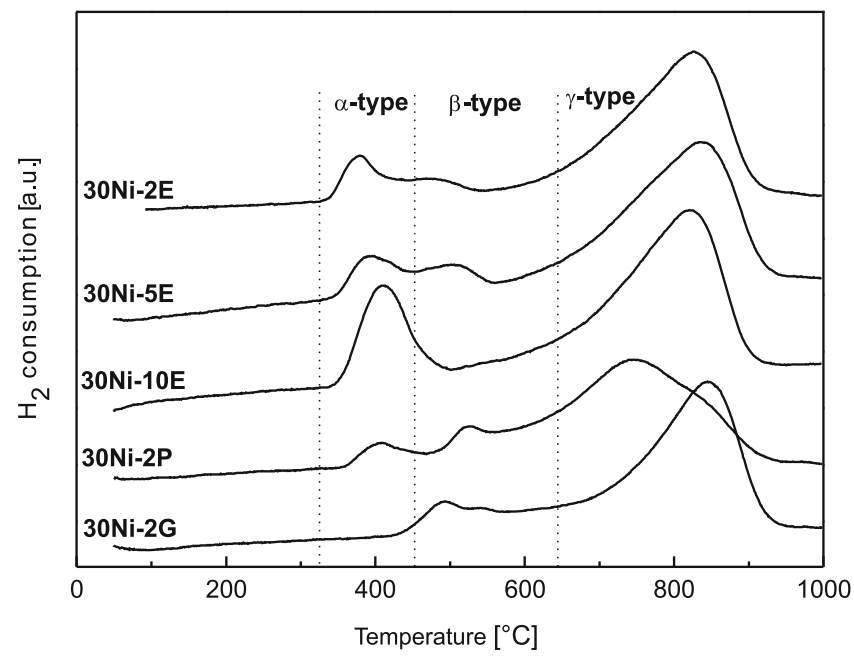

Figure 2. TPR profiles of fresh calcined $\mathrm{Ni}-\mathrm{Al}_{2} \mathrm{O}_{3}$ catalysts

and reported in literatures ${ }^{13-17}$, the reducible $\mathrm{NiO}$ species can be classified into three types: $\alpha, \beta$ and $\gamma$. The small peaks located in the low temperature region are assigned to $\alpha$-type $\mathrm{NiO}$ species (surface amorphous $\mathrm{NiO}$ or bulk $\mathrm{NiO}$ ), which are free nickel oxides species and have a weak interaction with alumina. The mild-temperature peaks represent $\beta$-type $\mathrm{NiO}$ species (weakly interacted with $\mathrm{Al}_{2} \mathrm{O}_{3}$ or called $\mathrm{Ni}$-rich phase), which are the main sources of low-temperature activity after reduction. The high-temperature peaks are assigned to $\gamma$-type $\mathrm{NiO}$ species (Strongly interact or chemically bound with $\mathrm{Al}_{2} \mathrm{O}_{3}$ ), which are ascribed to the stable nickel aluminate phase with a spinel structure ${ }^{18-20}$. In the same way, the XRD patterns prove that $\mathrm{NiAl}_{2} \mathrm{O}_{4}$ indeed exist in the Ni-based catalysts. It should be noted that $30 \mathrm{Ni}-10 \mathrm{E}$ and $30 \mathrm{Ni}-2 \mathrm{G}$ only have two peaks. This may because that peaks of different $\mathrm{NiO}$ species interlap, and in some cases, $\alpha$-type reduction peak would overlap with $\beta$-type. From the profiles of the catalysts prepared in ethanol, the low-temperature peaks move backward with the increase of the heating rate, and the same phenomenon is discovered in profiles of $30 \mathrm{Ni}-2 \mathrm{P}$ and $30 \mathrm{Ni}-2 \mathrm{G}$, which shows the interaction between surface $\mathrm{NiO}$ and $\mathrm{Al}_{2} \mathrm{O}_{3}$ of the catalysts with higher heating rate or prepared in n-propanol and glycerol is stronger than $30 \mathrm{Ni}-2 \mathrm{E}$.

TEM micrographs of reduced catalysts presented in Figure 3 clearly show that the nickel oxide particles are uniformly dispersed in the cotton-like $\gamma-\mathrm{Al}_{2} \mathrm{O}_{3}$. Mean particle size of $\mathrm{Ni}\left(\mathrm{D}_{\mathrm{Ni}}\right)$ determined from TEM (Nickel particles in the photo) is summarized in Table 1 (16.7-30.1 $\mathrm{nm}$ ), and varies in line with XRD, but a little higher than those calculated using Scherrer equation from XRD. This is because TEM measures polycrystal, while XRD counts monocrystalline Ni particles. Furthermore, particle size distribution is different from average Ni particle sizes ${ }^{21}$. As shown in TEM and particle size distribution images, comparing with $30 \mathrm{Ni}-5 \mathrm{E}, 30 \mathrm{Ni}-10 \mathrm{E}, 30 \mathrm{Ni}-2 \mathrm{P}$ and $30 \mathrm{Ni}-$ $-2 \mathrm{G}, 30 \mathrm{Ni}-2 \mathrm{E}$ retains narrower distribution and nearer space of Ni particles that would be beneficial for the activity and stability of the catalyst on account of making good use of catalyst surface area. Gao et al. ${ }^{22}$ found that Ni catalysts with particle size of $15-20 \mathrm{~nm}$ show a better performance. As shown in Figure 3f, 30Ni-2E retains a higher amount of particles between 15 and 20 $\mathrm{nm}$ than the other catalysts. It implies that $30 \mathrm{Ni}-2 \mathrm{E}$ has a higher catalytic activity. When the particle is too small or too large, it will lead to more carbon deposition and lower activity.

Figure $4 \mathrm{a}$ and $4 \mathrm{~b}$ presents the catalytic activity in terms of $\mathrm{CO}$ and $\mathrm{CO}_{2}$ conversion over $30 \mathrm{Ni}-2 \mathrm{E}, 30 \mathrm{Ni}-$ $5 \mathrm{E}, 30 \mathrm{Ni}-10 \mathrm{E}, 30 \mathrm{Ni}-2 \mathrm{P}$ and $30 \mathrm{Ni}-2 \mathrm{G}$ at $0.1 \mathrm{MPa}$ and $12000 \mathrm{~mL} \cdot \mathrm{g}^{-1} \cdot \mathrm{h}^{-1}$ during $260-340^{\circ} \mathrm{C}$. CO conversion of $30 \mathrm{Ni}-2 \mathrm{E}$ starts at $42.4 \%\left(260^{\circ} \mathrm{C}\right)$ and reaches nearly $100 \%$ below $320^{\circ} \mathrm{C}$, which shows a better activity than our previous work. As shown in Figure 4c, 30Ni-2E also reveals a high selectivity for methane, which approaches $100 \%$ after the temperature above $300^{\circ} \mathrm{C}$. The results indicate that catalytic activity decreases with the increase of heating rate, and the catalysts prepared in n-propanol and glycerol retain lower activity. As a result, it can be concluded that both heating rate and solvent play an important role in $\mathrm{Ni}$ particle size and distribution, affecting the catalytic activity of Ni-based catalysts for syngas methanation.

The production rate of methane per unit mass of nickel as a function of Ni crystal size was also studied at $280^{\circ} \mathrm{C}, 0.1 \mathrm{MPa}$ and $12000 \mathrm{~mL} \cdot \mathrm{g}^{-1} \cdot \mathrm{h}^{-1}$. Apparently, the production rate of methane per unit mass of nickel is greatly influenced by $\mathrm{Ni}$ particle size, which increases with $\mathrm{Ni}$ crystal size to a maximum i.e., 221 $\mathrm{mmol} \cdot \mathrm{g}^{-1} \cdot \mathrm{h}^{-1}$ at the mean size of $20.8 \mathrm{~nm}$ (determined by XRD), and then declines with a further increase in size, as shown in Table 1. This phenomenon indicates that the syngas methanation over $\mathrm{Ni}-\mathrm{Al}_{2} \mathrm{O}_{3}$ catalysts at 

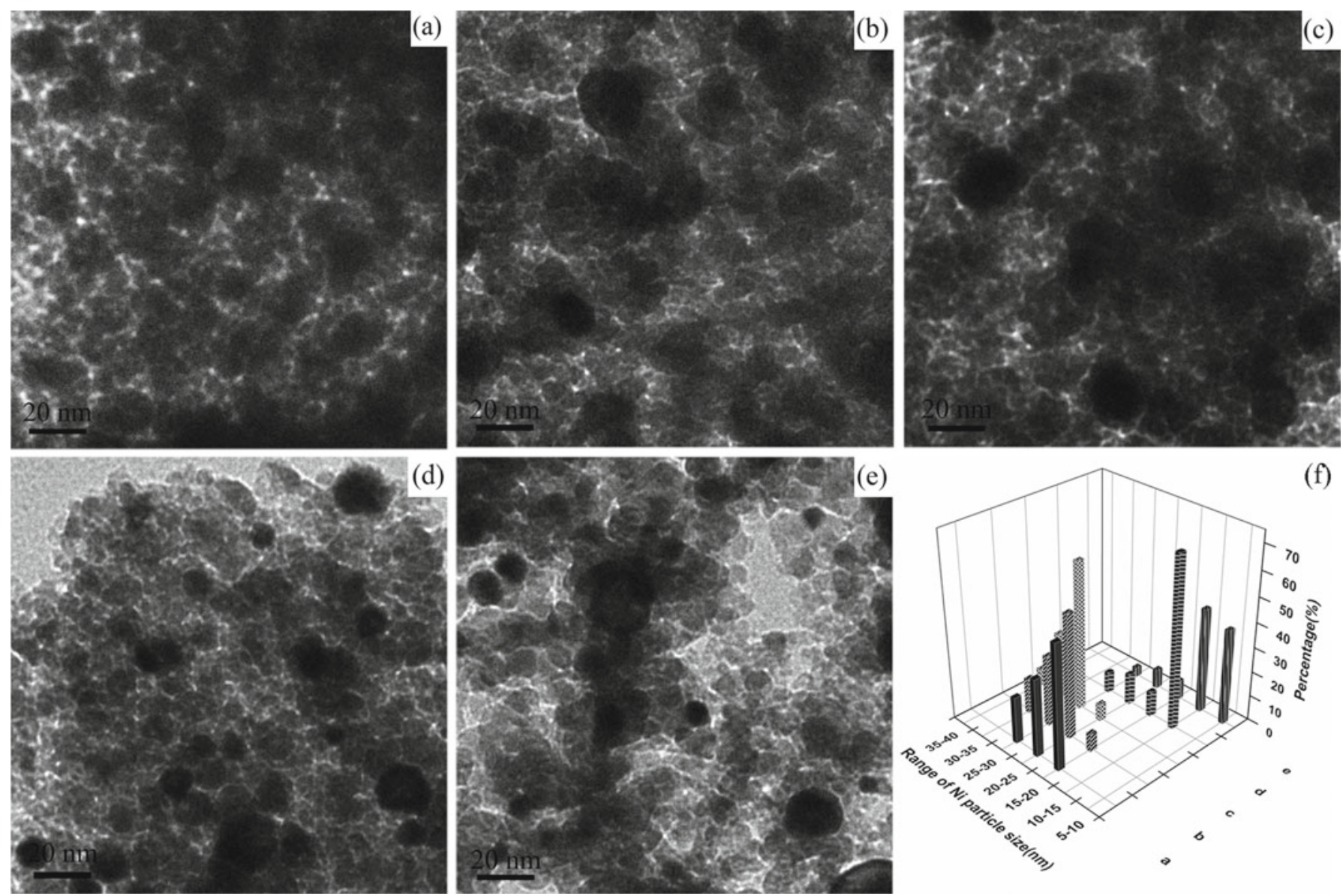

Figure 3. TEM micrographs of 30Ni-2E (a), 30Ni-5E (b), 30Ni-10E (c), 30Ni-2P (d), 30Ni-2G (e), and practical size distribution (f)
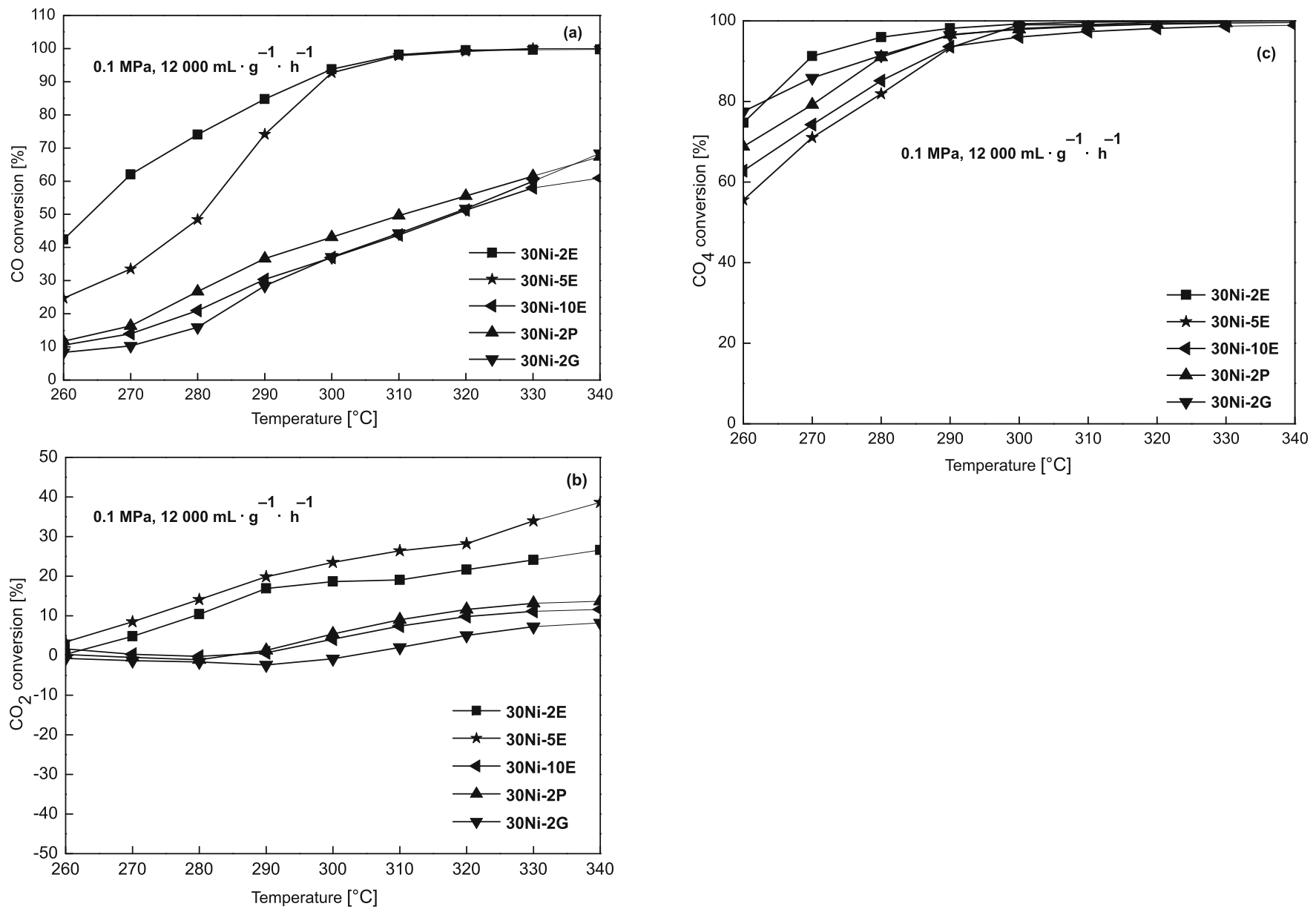

Figure 4. $\mathrm{CO}$ conversion (a), $\mathrm{CO}_{2}$ conversion (b), and $\mathrm{CH}_{4}$ selectivity (c) 
low-temperature is a structure-sensitive reaction. Larger $\mathrm{Ni}$ particles have a lower surface area for $\mathrm{CO}$ conversion and thus exhibit a lower methanation rate, while smaller Ni particles have a larger surface area for $\mathrm{CO}$ conversion which is beneficial for a higher methanation rate. However, smaller Ni particles, having amounts of $\mathrm{Ni}$ step sizes, are easily covered by carbon resulting in
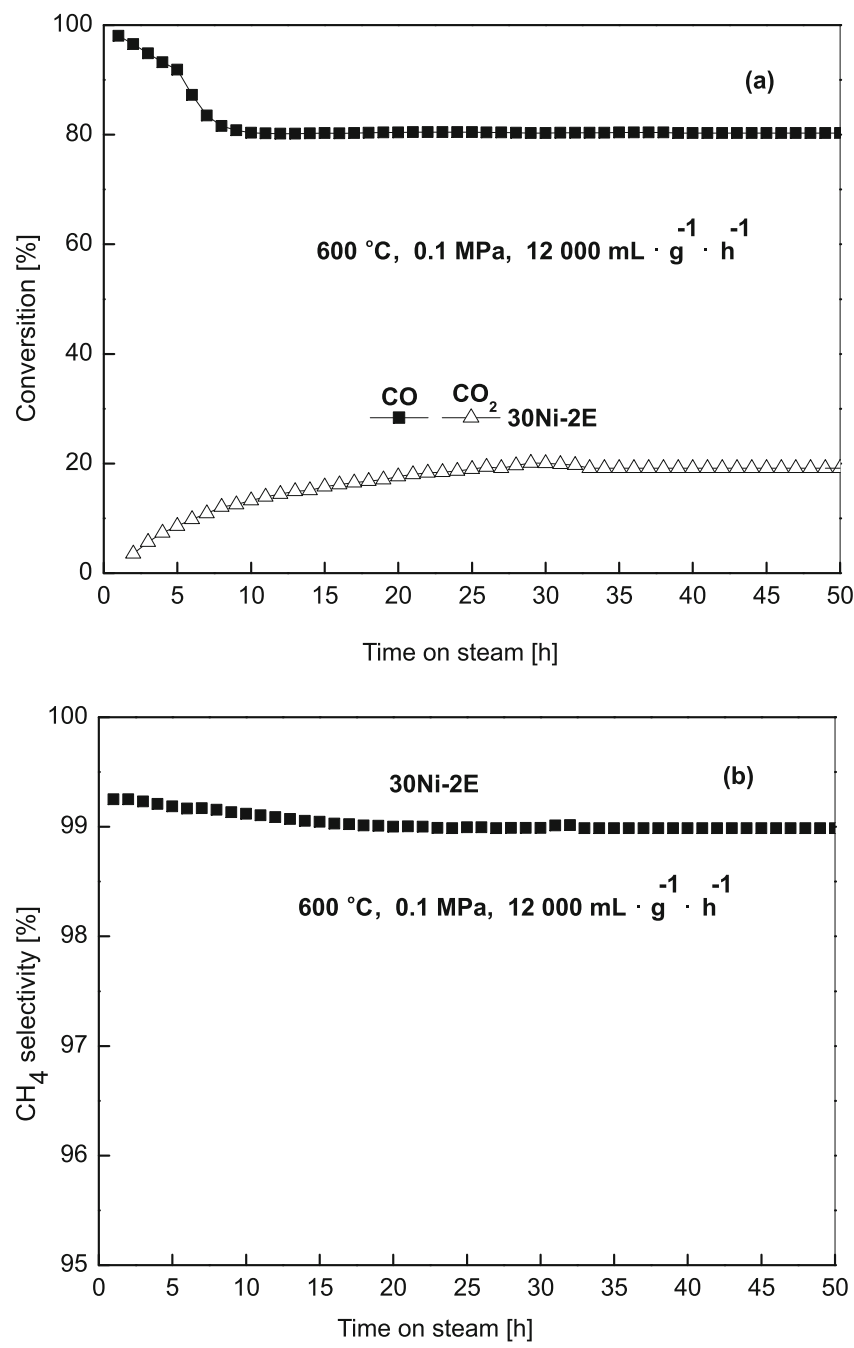

Figure 5. $\mathrm{CO}$ and $\mathrm{CO}_{2}$ conversion (a), and $\mathrm{CH}_{4}$ selectivity (b) for the stability test of $30 \mathrm{Ni}-2 \mathrm{E}$

fast deactivation of $\mathrm{Ni}$ catalysts, and thus have a low methanation rate ${ }^{23}$.

The stability test of $30 \mathrm{Ni}-2 \mathrm{E}$, the optimal catalyst among the five Ni-based catalysts, is conducted at $600^{\circ} \mathrm{C}$, $2 \mathrm{MPa}$ and $12000 \mathrm{~mL} \cdot \mathrm{g}^{-1} \cdot \mathrm{h}^{-1}$. In order to suppress the formation of both encapsulating carbon and filamentous carbon during syngas methanation reaction, $30 \mathrm{~mol} \%$ water vapor is added into the reaction system according to literature ${ }^{24}$. As shown in Figure 5a, with time on stream increase, the $\mathrm{CO}$ conversion of $30 \mathrm{Ni}-2 \mathrm{E}$ decreases gradually from 99.5 to $81.6 \%$, while $\mathrm{CO}_{2}$ conversion increases slowly to $\sim 20 \%$. Then the $\mathrm{CO}$ and $\mathrm{CO}_{2}$ conversion almost remain unchanged. Figure $5 \mathrm{~b}$ shows the $\mathrm{CH}_{4}$ selectivity, which maintains $\sim 99 \%$ during the whole life-time test. The good stability can be attributed to that $\mathrm{Ni}$ particles are scattered and spatially isolated by $\mathrm{Al}_{2} \mathrm{O}_{3}$, which can prevent the sintering of $\mathrm{Ni}$ particles. It proves $30 \mathrm{Ni}-2 \mathrm{E}$ catalyst not only has optimal catalytic activity at low-temperature, but also shows good stability at high-temperature.

\section{CONCLUSIONS}

$\mathrm{Ni}-\mathrm{Al}_{2} \mathrm{O}_{3}$ catalysts prepared by SCM for syngas methanation are enhanced by adopting various heating rate $\left(2^{\circ} \mathrm{C} \cdot \min ^{-1}, 5^{\circ} \mathrm{C} \cdot \mathrm{min}^{-1}\right.$ and $\left.10^{\circ} \mathrm{C} \cdot \mathrm{min}^{-1}\right)$ and different solvent (ethanol, n-propanol and glycerol). Both heating rate and solvent have effects on Ni particle size, thus affecting the catalytic activity. $30 \mathrm{Ni}-2 \mathrm{E}$ prepared in ethanol at $2^{\circ} \mathrm{C} \cdot \mathrm{min}^{-1}$ exhibits better catalytic activity. In addition, the production rate of methane per unit mass of nickel is greatly influenced by $\mathrm{Ni}$ particle size. The maximum production rate of methane per unit mass of nickel can be achieved to $221 \mathrm{mmol} \cdot \mathrm{g}^{-1} \cdot \mathrm{h}^{-1}$ on around $20.8 \mathrm{~nm}$ $\mathrm{Ni}$ particles (determined by XRD), at $280^{\circ} \mathrm{C}, 0.1 \mathrm{MPa}$ and $12000 \mathrm{~mL} \cdot \mathrm{g}^{-1} \cdot \mathrm{h}^{-1}$.

\section{ACKNOWLEDGMENT}

This work is financially supported by the National Science and Technology Supporting Plan (2012AA050102).

\section{LITERATURE CITED}

1. Kopyscinski, J., Schildhauer, T.J. \& Biollaz, S.M.A. (2010). Production of synthetic natural gas (SNG) from coal and dry biomass-A technology review form 1950 to 2009. Fuel. 89(8), 1763-1783. DOI: 10.1016/j.fuel.2010.01.027.

2. Gao, J.J., Wang, Y.L., Ping, Y., Hu, D.C., Xu, G.W., Gu, F.N. \& Su, F.B. (2012). A thermodynamic analysis of methanation reactions of carbon oxides for the production of synthetic natural gas. RSC Adv. 2(6), 2358-2368. DOI: 10.1039/c2ra00632d.

3. Xavier, K.O., Sreekala, R., Rashid, K.K.A., Yusuf, K.K.M. \& Sen, B. (1999). Doping effects of cerium oxide on $\mathrm{Ni} / \mathrm{Al}_{2} \mathrm{O}_{3}$ catalysts for methanation. Catal. Today. 49(1-3), 17-21. DOI: 10.1016/S0920-5861(98)00403-9.

4. Derekaya, F.B. \& Yasar, G. (2011). The CO methanation over $\mathrm{NaY}$-zeolite supported $\mathrm{Ni} / \mathrm{Co}_{3} \mathrm{O}_{4}, \mathrm{Ni} / \mathrm{ZrO}_{2}, \mathrm{Co}_{3} \mathrm{O}_{4} / \mathrm{ZrO}_{2}$ and $\mathrm{Ni} / \mathrm{Co}_{3} \mathrm{O}_{4} / \mathrm{ZrO}_{2}$ catalysts. Catal. Commun. 13(1), 73-77. DOI: $10.1016 /$ j.catcom.2011.06.024.

5. Kopyscinski, J., Schildhauer, T.J. \& Biollaz, S.M.A. (2011). Fluidized-Bed methanation: Interaction between kinetics and mass transfer. Ind. Eng. Chem. Res. 50(5), 2781-2790. DOI: 10.1021/ie100629k.

6. Duan, X.Z., Qian, G., Zhou, X.G., Sui, Z.J., Chen, D. \& Yuan, W.K. (2011). Tuning the size and shape of Fe nanoparticles on carbon nanofibers for catalytic ammonia decomposition. Appl. Catal. B: Environ. 101(3-4), 189-196. DOI: 10.1016/j. apcatb.2010.09.017.

7. Utaka, T., Takeguchi, T., Kikuchi, R. \& Eguchi, K. (2003). $\mathrm{CO}$ removal from reformed fuels over $\mathrm{Cu}$ and precious methal catalysts. Appl. Catal. A: Gen. 246(1), 117-124. DOI: 10.1016/ S0926-860X(03)00048-6.

8. Vannice, M.A. (1975). The catalytic synthesis of hydrocarbons form $\mathrm{H}_{2} / \mathrm{CO}$ mixtures over the group VIII methas: 1 . The specific activities and product distributions of supported metals. J. Catal. 37(3), 449-461. DOI: 10.1016/00214-9517(75)90181-5.

9. Kim, S.H., Lee, W.D. \& Lee, H.I. (2013). Effect of $\mathrm{CeO}_{2}$ on $\mathrm{CO}$ removal over $\mathrm{CeO}_{2}$-modified $\mathrm{Ni}$ catalyst in $\mathrm{CO}$-rich syngas. Korean J. Chem. Eng. 30(4), 860-863. DOI: 10.1007/ s11814-013-0007-x.

10. Wieslawa, C.B. (2013). Influence of the exchanged metal ions $(\mathrm{Cu}, \mathrm{Co}, \mathrm{Ni}$ and $\mathrm{Mn})$ on the selective catalytic reduction of NO with hydrocarbons over modified ferrierite. Pol. J. Chem. Tech. 15(2), 10-15. DOI: 10.2478/pjct-2013-0018. 
11. Shi, P. \& Liu, C.J. (2009). Characterization of silica supported nickel catalyst for methanation with improved activity by room temperature plasma treatment. Catal. Lett. 133(1-2), 112-118. DOI: 10.1007/s10562-009-0163-0.

12. Zhao, A.M., Ying, W.Y., Zhang, H.T., Ma, H.F. \& Fang, D.Y. (2012). $\mathrm{Ni}-\mathrm{Al}_{2} \mathrm{O}_{3}$ catalysts prepared by solution combustion method for syngas methanation. Catal. Commun. 17, 34-38. DOI: $10.1016 /$ j.catcom.2011.10.010.

13. Zhang, J., Xu, H.Y., Jin, X.L., Ge, Q.J. \& Li, W.Z. (2005). Characterizations and activities of the nano-sized $\mathrm{Ni} / \mathrm{Al}_{2} \mathrm{O}_{3}$ and $\mathrm{Ni} / \mathrm{La}-\mathrm{Al}_{2} \mathrm{O}_{3}$ catalysts for $\mathrm{NH}_{3}$ decomposition. Appl. Catal. A: Gen. 290(1-2), 87-96. DOI: 10.1016/j.apcata.2005.05.020.

14. Guimon, C., Auroux, A., Romero, E. \& Monzon, A. (2003). Acetylene hydrogenation over $\mathrm{Ni}-\mathrm{Si}-\mathrm{Al}$ mixed oxides prepared by sol-gel technique. Appl. Catal. A: Gen. 251(1), 199-214. DOI: 10.1016/S0926-860X(03)00318-1.

15. Zhang, Y.H., Xiong, G.X., Sheng, S.S., Liu, S.L. \& Yang, W.S. (1999). Interaction of $\mathrm{NiO}$ with $\gamma-\mathrm{Al}_{2} \mathrm{O}_{3}$ supporter of $\mathrm{NiO} / \gamma-\mathrm{Al}_{2} \mathrm{O}_{3}$ catalysts. Acta Phys. Chem. Sim. (Wuli Huaxue Xuebao) 15(8), 735-741. DOI: 10.3866/PKU.WHXB19990813.

16. Rynkowski, J.M., Paryjczak, T. \& Lenik, M. (1993). On the nature of oxidic nickel phases in $\mathrm{NiO} / \gamma-\mathrm{Al}_{2} \mathrm{O}_{3}$ catalysts. Appl. Catal. A: Gen. 106(1), 73-82. DOI: 10.1016/0926-860X(93)80156-K.

17. Vos, B., Poels, E. \& Bliek, A. (2001). Impact of calcination conditions on the structure of alumina-supported nickel particles. J. Catal. 198(1), 77-88. DOI: 10.1006/jcat.2000.3082.

18. Zou, X.J., Wang, X.G. \& Li, L. (2010). Development of highly effective supported nickel catalysts for pre-reforming of liquefied petroleum gas under low steam to carbon molar ratios. Int. J. Hydrogen. Energ. 35(22), 12191-12200. DOI: 10.1016/j.ijhydene.2010.08.080.

19. Yang, J., Wang, X.G., Li, L., Shen, K., Lu, X.G. \& Ding, W.Z. (2010). Catalytic conversion of tar from hot coke oven gas using 1-methylnaphthalene as a tar model compound. Appl. Catal. B: Environ. 96(1-2), 232-237. DOI: 10.1016/j. apcatb.2010.02.026.

20. Koo, K.Y., Roh, H.S., Seo, Y.T., Seo, D.J., Yoon, W.L. \& Park, S.B. (2008). A highly effective and stable nano-sized $\mathrm{Ni} / \mathrm{MgO}-\mathrm{Al}_{2} \mathrm{O}_{3}$ catalyst for gas to liquids (GTL) process. Int. J. Hydrogen. Energ. 33(8), 2036-2043. DOI: 10.1016/j. ijhydene.2008.02.029.

21. Xin, Q. \& Luo, M.F. (2009). Xian Dai Cui Hua Yan Jiu Fang Fa (1st ed). Beijing: Science Press.

22. Gao, J.J., Jia, C., Zhang, M.J., Gu, F., Xu, G.W. \& Su, F.B. (2013). Effect of nickel nanoparticle size in $\mathrm{Ni} / \alpha-\mathrm{Al}_{2} \mathrm{O}_{3}$ on $\mathrm{CO}$ methanation reaction for the production of synthetic natural gas. Catal. Sci. Technol. 3(8), 2009-2015. DOI: 10.1039/ C3CY00139C.

23. Chen, D., Christensen, K.O., Ochoa-Fernandez, E., Yu, Z.X., Totdal, B., Latorre, N., Monzon, A. \& Holmen, A. (2005). Synthesis of carbon nanofibers: effects of Ni crystal size during decomposition. J. Catal. 229(1), 82-96. DOI: 10.1016/j. jcat.2004.10.017.

24. Jimeneza, V., Sancheza, P., Panagiotopouloub, P., Valverdea, J.L. \& Romeroa, A. (2010). Methanation of $\mathrm{CO}, \mathrm{CO}_{2}$, and selective methanation of $\mathrm{CO}$, in mixtures of $\mathrm{CO}$ and $\mathrm{CO}_{2}$, over ruthenium carbon nanofibers catalysts. Appl. Catal. A: Gen. 390(1-2), 35-44. DOI: 10.1016/j.apcata.2010.09.026. 